\title{
PERCEPTIONS OF USEFULNESS AND PERCEPTIONS OF EASINESS TO EMPLOYEES INTEREST IN USING FINTECH
}

Sri Mulyati ${ }^{\star 1}$, Bambang Sugiharto ${ }^{2}$, Prini Nurtina Dewi ${ }^{3}$

1,2, 3Sekolah Tinggi IImu Ekonomi Sutaatmadja srimulyati@stiesa.ac.id

\begin{tabular}{l} 
INFO ARTIKEL \\
\hline Histori Artikel : \\
Tgl. Masuk : 01 September 2020 \\
Tgl. Diterima : 29 Swptember 2020 \\
Tersedia Online : 29 September 2020 \\
\hline Keywords: \\
Usability, Ease, Interest in using, \\
FinTech
\end{tabular}

\begin{abstract}
This study aims to examine the effect of perceived usefulness and perceived convenience on the interests of Lima Motor Subang employees in using fintech. The population used in this study were employees of Lima Motor Subang, with sample selection techniques using saturated sampling, and obtained 47 respondents. Data testing used in this research is multiple regression analysis, then to test the hypothesis using the $F$ test, $t$ test and the coefficient of determination (R2) with SPSS software version 22.0. The results of this study indicate that the variable of perceived usefulness and perceived convenience both partially and simultaneously affect the interest in using fintech.
\end{abstract}

\section{PENDAHULUAN}

\begin{abstract}
Perkembangan teknologi yang pesat dan didukung oleh penguatan inftrastuktur teknologi membawa kita masuk ke era digitalisasi. Masuknya era digital, hampir semua data yang kita butuhkan ada di internet sehingga kita bisa melakukan aktivitas dengan cepat, akurat dan tentunya lebih mudah. Inovasi perkembangan teknologi dan kecerdasan tidak lepas mempengaruhi industri keuangan dan tata kelola. Munculnya financial technology (fintech) dalam berbagai platform kini dirasakan oleh masyarakat (Elshabyta, 2018). Menurut Bank Indonesia, financial technology atau lebih dikenal dengan istilah fintech itu adalah hasil gabungan dari jasa keuangan dengan teknologi dan akhirnya mengubah gaya bisnis dari konvensional menjadi moderat, yang awalnya sistem pembayaran dilakukan dengan bertatap muka dengan membawa sejumlah uang kas, kini bisa dilakukan transaksi jarak jauh dan dilakukan dalam hitungan detik.
\end{abstract}

\begin{abstract}
Fintech merupakan sebuah layanan keuangan digital dimana membayar tanpa harus ada bentuk fisik, layanan inilah yang akan mengubah sistem pembayaran secara tunai dan konvensional dalam masyarakat. Keberadaan dan aplikasi pengguna fintech di indonesia harus tetap berkembang baik dari sisi pemerintah maupun masyarakat (Elshabyta, 2018). Seiring dengan perkembangan teknologi, fintech menjadi solusi yang menjadi tren dunia. Crowdfunding menjadi solusi simpan pinjaman populer di berbagai negara maju. Epayment menjadi salah satu solusi atau bentuk yang berkembang dan banyak diminati, tentunya berbagai keuntungan yang telah diperoleh dari solusi epayment di Indonesia karena pengguna merasakan kemudahan dalam bertransaksi, mudah dipelajari dan lebih efisien (Junadi \& Sfenrianto, 2015).
\end{abstract}

Electronic Payment (Epayment) atau pembayaran elektronik yaitu suatu pembayaran yang dilaksanakan secara 
elektronik. Didalam pembayaran elektronik uang disimpan, diproses dan diterima dalam bentuk informasi digital dan proses pemindahannya melalui alat pembayaran elektronik. Pembayaran secara tradisional dilakuan melalui uang tunai, cek atau kartu kredit sedangan pembayaran elektronik dilakukan menggunakan software tertentu, kartu pembayaran dan uang elektronik. Komponen-komponen utama dari sistem pembayaran elektronik anatara lain; aplikasi pemindahan uang, infrastuktur jaringan, peraturan dan prosedur yang memerintah kegunaan dari sistem tersebut (Deni, 2008).

Tidak di pungkiri bahwa karyawan adalah salah satu golongan yang sebagian besar menggunakan produk fintech pada jenis epayment, begitu juga karyawan Lima Motor Subang. Karyawan adalah segment pasar yang potensial sebagai pengguna epayment, karena beberapa alasan. Pertama, karyawan saat ini sebagian besar akrab dengan teknologi. Kedua, mobilitas karyawan yang memerlukan transportasi berbasis epayment relatif tinggi (Grab, Go-jek dan lain-lain). Pada dasarnya sebuah layanan yang mampu memberikan manfaat pada pengguna pasti akan diterima dengan baik. Semakin pengguna merasa bahwa fintech bermanfaat maka fintech akan semakin sering digunakan. Begitu juga sebaliknya, apabila pengguna menganggap fintech kurang bermanfaat maka pengguna akan cenderung mengabaikan fintech tersebut. Sebuah sistem yang dianggap rumit biasanya tidak akan digunakan oleh penggunanya, padahal tolak ukur penerimaan sebuah sistem dilihat dari penggunaanya. Suatu sistem yang sering digunakan menunjukkan lebih dikenal, lebih mudah dioperasikan dan lebih mudah digunakan (Irmadhani, Mahendra 2012).
(Yaumil, 2017) seseorang akan menilai apabila sesuatu bermanfaat untuk dirinya maka disaat itulah dia akan berminat untuk menggunakan dan akan mendapat kepuasan. Minat bisa dipengaruhi oleh beberapa faktor seperti kemanfaatan dan kemudahan. Menurut Davis, Bagozzi, Warshaw (1989) menyatakan bahwa presepsi manfaat mempunyai dampak langsung terhadap tujuan pengadopsian suatu teknologi, sedangkan persepsi kemudahan pengguna mempunyai dampak langsung maupun tidak langsung terhadap tujuan pengadopsian melalui persepsi manfaat. Sedangkan menurut Jogiyanto, 20017) pengguna sistem akan menggunakan sistem tersebut jika bermanfaat, baik sistem itu mudah digunakan atau tidak mudah digunakan. Sedangkan menurut Khoirul Basyar, Sanaji (2016) persepsi manfaat merupakan suatu ukuran dimana penggunaan suatu teknologi dipercaya akan mendatangkan manfaat bagi orang yang menggunakannya.

Persepsi kemudahan memberikan indikasi bahwa suatu sistem dirancang bukan untuk menyulitkan penggunanya, tetapi justru mempermudah seseorang dalam menyelesaikan pekerjaanya. Dengan kata lain, seseorang yang menggunakan sistem akan berkerja lebih mudah dibandingkan dengan seseorang yang tidak menggunakan sistem atau bekerja secara manual (Hadi dan Novi, 2015). Sedangkan menurut Pengukuran persepsi kemudahan mengadaptasi dari penelitian Pavlou (2003) dalam Sanaji (2016) yaitu situs yang jelas dan dapat dimengerti, tidak memerlukan usaha yang berlebih, mudah menemukan informasi yang dibutuhkan dan mudah untuk digunakan. Setiap teknologi diciptakan untuk mempermudah aktivitas individu, tentu saja kehadiran fintech ini juga mempermudah karyawan dalam 
aktivitasnya. Seperti pada PD Lima Motor Subang, banyak dari karyawannya sudah menggunakan produk fintech. Berdasarkan hasil penelitian sekitar 82,9\% karyawan PD Lima Motor Subang telah menggunakan produk fintech. Penelitian ini dilakukan pada karyawan PD Lima Motor Subang, untuk melihat bagaimana persepsi karyawan terhadap penggunaan fintech. karena meskipun hamper semua karyawan PD Lima Motor Subang ini sudah menggunakan produk fintech, ternyata masih ada juga karyawan yang belum menggunakan produk fintech, karena merasa masih kesulitan dalam menggunakan aplikasi dari produk fintech dan pengguna teknologi lebih cenderung menggunakan smartphone nya untuk games online atau menonton sesuatu yang tidak bermanfaat dan hal semacamnya untuk sesuatu yang tidak jelas.

\section{KERANGKA TEORITIS DAN PENGEMBANGAN HIPOTESIS}

Pengertian Fintech yang dijabarkan oleh National Digital Research Centre (NDRC) yaitu istilah yang digunakan untuk menyebut suatu inovasi dibidang jasa finansial yang mengacu pada inovasi financial dengan sentuhan teknologi modern. Fintech merupakan salah satu bentuk penerapan teknologi informasi dibidang keuangan dengan muncul berbagai model keuangan baru dimulai pertama kali pada tahun 2004 oleh Zopa, yaitu institusi keuangan yang berada di Inggris yang menjalanan jasa peminjaman uang. Beberapa usaha fintech yang ada seperti ; (1) Crowdfunding dan Peer To Peer Lending; (2) Payment, Clearing dan Settlement; (3) Market Aggregator; (4) Manajemen Risiko dan Investasi.

Di Indonesia banyak perusahaan startup yang memakai jasa layanan
FinTech dan berbasis teknologi digital seperti seperti Gojek, Grab, dan Uber. Di Indonesia FinTech di kenal lebih baik jika dibandingkan dengan bisnis konvensional yang memiliki citra yang biasa saja dan tidak efisien. Usaha fintech juga menggunakan data dari sosial media, seperti aktivitas sosial media yang dapat dijadikan bagian dari analisis resiko. Fintech adalah sebagai solusi bagi masyarakat khususnya generasi milenial, kehadiran fintech bukanlah sebagai penantang terhadap bidang perbankan.

Oleh karena itu minat menggunakan fintech dalam memenuhi kebutuhan semakin berkembang dikalangan masyarakat terutama kaum milenial. Minat muncul dari masing-masing individu ketika dihadapkan pada beberapa pilihan mengenai benda, aktivitas atau hal tertentu untuk kemudian menentukan satu untuk pilihannya, Yaumil (2017). Sedangkan menurut Hu et al (1999) dalam Ari (2013) minat menggunakan merupakan suatu keinginan seseorang untuk tetap menggunakan suatu barang tersebut. Indikator-indikator yang digunakan untuk mengetahui minat perilaku adalah sebagai berikut : (1) Niat untuk menggunakan; (2) Kecenderungan untuk menggunakan; (3) Prediksi melanjutkan untuk menggunakan dimasa depan; (4) Niat untuk menggunakan di masa depan.

Teori yang mendasari penelitian ini adalah Technology Acceptance Model (TAM). Daviz, Bagozzi \& Warshaw (1989) menyebutkan Untuk mengetahui tingkat penerimaan sebuah teknologi baru di masyarakat dilakukan salah satunya dengan model TAM yang sudah umum digunakan untuk mengukur perilaku penerimaan terhadap suatu teknologi baru. TAM adalah pengembangan dari TRA (Theory Reasoned Action) yang sebenarnya fokus kajiannya adalah pada perilaku psikologis seseorang terhadap 
suatu objek. Model klasik TAM menggunaan faktor sikap pada beberapa variabel yaitu : (1) Kemudahan dalam pengguna; (2) Kemanfaatan.

Menurut Davis dalam Rithmaya (2016) Manfaat adalah suatu ukuran dimana pengguna suatu teknologi dipercaya akan mendatangan manfaat bagi orang yang menggunaannya. Kemampuan subjektif pengguna dimasa yang akan datang dimana dengan menggunakan sistem aplikasi yang spesifik aan meningkatkan kinerja dalam konteks organisasi. Persepsi kemanfaatan diukur melalui indikator seperti : (1) Meningkatkan kinerja pekerjaan; (2) Menjadikan pekerjaan lebih mudah; (3) Keseluruhan teknologi yang digunakan dirasakan bermanfaat. Yahyapor (2008) menambahkan bahwa persepsi kemanfaatan dapat diukur dengan indikator sebagai berikut : (1) Meningkatkan produktivitas; (2) Menjadikan kerja lebih efektif; (3) Serta pekerjaan lebih cepat.

Persepsi kemudahan seperti yang dikemukakan oleh Wibowo (2006) menyatakan bahwa persepsi tentang kemudahan pengguna sebuah teknologi didefiniskan sebagai salah satu ukuran dimana seseorang percaya bahwa teknologi tersebut dapat dengan mudah dipahami dan digunakan. Sedangkan menurut Vanketsh dan Davis (2002) dalam Widiyanto dan Prasilowati (2015) menyebutkan bahwa kemudahan merupakan persepsi seseorang yang tidak direpotkan dengan berbagai kegiatan lain dalam melakukan transaksi.

Menurut Vankatesh dan Davis (2000) dalam Widiyanto dan Prasilowati (2015), indikator kemudahan meliputi: (1) Teknologi informasi mudah untuk dipelajari (easy to learn); (2) Teknologi informasi mengerjakan dengan mudah apa yang diinginkan pengguna; (3) Ketrampilan pengguna akan bertambah dengan menggunakan teknologi informasi; (4) Teknologi sangat mudah untuk dioperasikan.

\section{Pengaruh Persepsi Kebermanfaatan Terhadap Minat Menggunakan Fintech}

Davis (1989) mendefinisikan kemanfaatan sebagai suatu tingkatan dimana seseorang percaya bahwa penggunaan suatu subyek tertentu akan akan dapat meningkatkan prestasi kerja orang tersebut. Davis (1989) juga membuktikan bahwa manfaat mempunyai hubungan yang kuat dan konsisten dengan penerimaan teknologi informasi dibandingkan dengan variabel lain. Hasil penelitian Penelitian Rurie Wiedya Rahayu (2018) menunjukkan bahwa Persepsi manfaat berpengaruh signifikan positif terhadap minat menggunakan go pay. Ini berarti pula bahwa semakin dirasa bermanfaat maka penggunaan go pay akan semakin meningkat. Demikian pula dapat berlaku bagi penggunaan fintech, semakin seseorang merasakan manfaatnya maka penggunaan fintech akan semakin meningkat. Dari penelitian terdahulu tersebut maka dapat ditarik hipotesis sebagai berikut:

H1: Persepsi kebermanfaatan
berpengaruh positif terhadap Minat
Menggunaka Fintech.

\section{Pengaruh Persepsi Kemudahan terhadap Minat menggunakan Fintech}

Vankatesh dan Davis (2000) mengemukakan bahwa kemudahan merupakan persepsi seseorang yang tidak direpotkan dengan berbagai kegiatan lain dalam melakukan transaksi. Maka seseorang akan cenderung untuk lebih berminat pada suatu produk tersebut apabila produk tersebut tidak merepotkan 
dalam penggunaannya. Wang (2002) menemukan bahwa kemudahan penggunaan merupakan variabel terkuat dalam menentukan minat seseorang. Hasil penelitian Muhammad Wildan (2019) menunjukkan bahwa Persepsi kemudahan penggunaan berpengaruh positif dan signifikan terhadap minat bertransaksi menggunakan Fintech. Hal ini dapat diartikan bahwa ketika penggunaan fintech dirasa semakin mudah bagi seseorang, maka akan semakin sering baginya menggunakan fintech. Dari penelitian terdahulu tersebut maka dapat ditarik hipotesis sebagai berikut:

$\mathrm{H} 2$ : $\quad$ Persepsi kemudahan berpengaruh positif terhadap Minat Menggunaka Fintech.

\section{METODOLOGI PENELITIAN}

Jenis data yang digunakan dalam penelitian ini adalah data kuantitatif, sumber data yang digunakan yaitu data primer, dan teknik pengumpulan data yang digunakan adalah kuesioner. Populasi pada penelitian ini yaitu karyawan Lima Motor Subang, teknik pengambilan sampel menggunakan metode sampling jenuh dan diperoleh 47 responden.

Variabel dalam penelitian ini terdiri dari variabel independen yang terdiri dari persepsi kebermanfaatan dan persepsi kemudahan, sedangkan variabel dependennya adalah minat menggunakan fintech. Teknik analisis data yang dilakukan dengan tahapan sebagai berikut : analisis statistic deskriptif, uji normalitas, uji outlier, uji asumsi klasik dan pengujian hipotesis dengan analisis regresi berganda.

\section{HASIL DAN PEMBAHASAN}

Deskripsi Responden

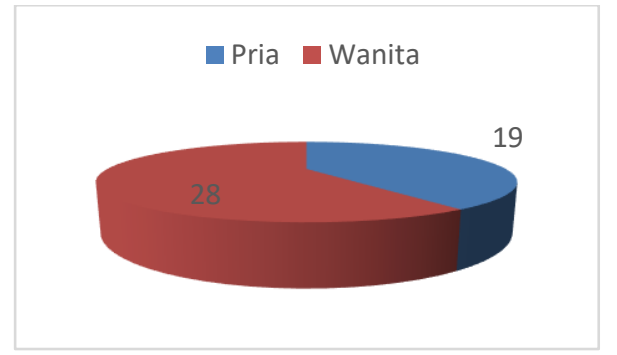

\section{Bagan 1. Klasifikasi Responden Berdasarkan Jenis Kelamin}

\section{Sumber : data diolah 2019}

Berdasarkan data di atas bahwa jumlah responden pria dari total keseluruhan responden adalah 19 orang atau 40,43\% sedangkan jumlah responden wanita adalah sebanyak 28 orang atau $59,57 \%$.



\section{Bagan 2. Klasifikasi Responden Berdasarkan Pernah Menggunakan Fintech.}

\section{Sumber : data diolah 2019}

Berdasarkan data di atas bahwa jumlah responden yang pernah menggunakan fintech adalah 39 Karyawan Lima Motor Subang atau $82,98 \%$ dari total keseluruhan responden, sedangkan jumlah responden yang belum pernah menggunakan adalah sebanyak 8 
Karyawan Lima Motor Subang atau $17,02 \%$ dari total keseluruhan responden.

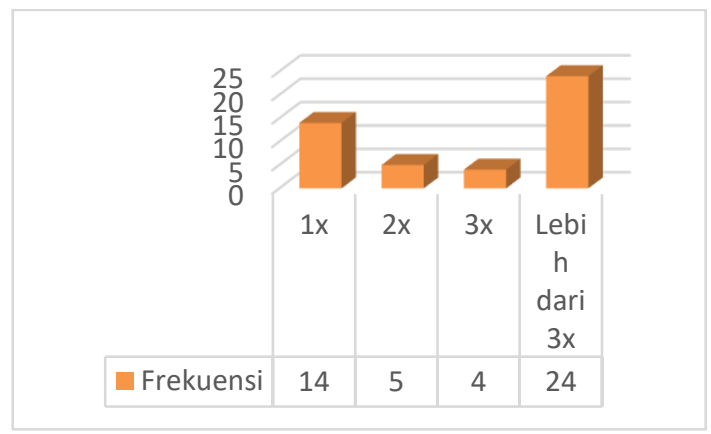

\section{Bagan 3. Klasifikasi Responden Berdasarkan Keperluan Pengguna}

\section{Sumber : data diolah 2019}

Berdasarkan data di atas bahwa jumlah responden yang menggunakan Fintech dengan keperluan Pembayaran adalah 36 Karyawan Lima Motor Subang atau $76,60 \%$ dari total keseluruhan responden, responden yang menggunakan Fintech dengan keperluan Pinjaman Uang adalah 2 Karyawan Lima Motor Subang atau $4,26 \%$ dari total keseluruhan responden responden yang menggunakan Fintech dengan keperluan Trading Saham adalah 2 Karyawan Lima Motor Subang atau $14,89 \%$ dari total keseluruhan responden, responden yang menggunakan Fintech dengan keperluan Lainnya adalah 7 Karyawan Lima Motor Subang atau $14,89 \%$ dari total keseluruhan responden,

Bagan 4. Klasifikasi Responden Berdasarkan Frekuensi Pengguna

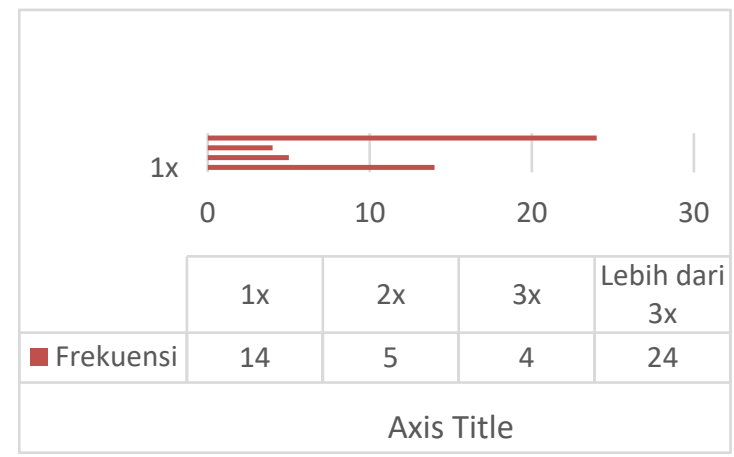

Berdasarkan data diatas bahwa jumlah responden yang menggunakan Fintech dengan Frekuensi 1x adalah 14 Karyawan Lima Motor Subang atau 29,79\% dari total keseluruhan responden, responden yang menggunakan Fintech dengan Frekuensi 2x adalah 5 Karyawan Lima Motor Subang atau $10,64 \%$ dari total keseluruhan responden, responden yang menggunakan Fintech dengan Frekuensi $3 x$ adalah 4 Karyawan Lima Motor Subang atau $8,51 \%$ dari total keseluruhan responden, sedangkan responden yang menggunakan Fintech dengan Frekuensi lebih dari 3x adalah 24 Karyawan Lima Motor Subang atau $51,06 \%$ dari total keseluruhan responden

\section{Tabel 2. Analisis Linier Berganda}

Sumber : data diolah,2019.

\begin{tabular}{|c|c|c|c|c|c|}
\hline \multicolumn{2}{|c|}{$\begin{array}{l}\text { Unstandardized } \\
\text { Coefficients }\end{array}$} & \multicolumn{2}{|c|}{$\begin{array}{l}\text { Standar } \\
\text { dized } \\
\text { Coeffici } \\
\text { ents }\end{array}$} & \multirow[b]{2}{*}{ Sig. } & \\
\hline B & $\begin{array}{l}\text { Std. } \\
\text { Erro }\end{array}$ & Beta & $\mathrm{t}$ & & \\
\hline $\begin{array}{l}\text { (Constan } \\
\text { t) }\end{array}$ & -.074 & 1.581 & & $\begin{array}{r}- \\
.047\end{array}$ & .963 \\
\hline $\mathrm{X} 1$ & ,279 & ,080 & ,487 & $\begin{array}{r}3,51 \\
2\end{array}$ & ,001 \\
\hline $\mathrm{X} 2$ & 270 & ,093 & ,402 & $\begin{array}{r}2,89 \\
4\end{array}$ & ,006 \\
\hline F -Value & & & & & $\begin{array}{r}56,1 \\
64\end{array}$ \\
\hline Prob (F) & & & & & $\begin{array}{r}, 000 \\
\text { b }\end{array}$ \\
\hline $\begin{array}{l}\text { Adjusted } \\
\mathrm{R}^{2}\end{array}$ & & & & & $\begin{array}{r}0,70 \\
6\end{array}$ \\
\hline
\end{tabular}

\section{Hasil Pengujian Hipotesis}

Setelah melalui serangkaian pengujian, semua variabel dalam penelitian ini memenuhi hasil uji validitas dan reliabilitas. Berikut ini merupakan hasil 
untuk regresi berganda untuk membuktikan adanya pengaruh atau tidak adanya pengaruh dari variabel persepsi kerbermanfaatan (X1), persepsi kemudahan (X2), dan minat menggunakan fintech $(\mathrm{Y})$.

Berdasarkan dari tabel hasil analisis regresi berganda menghasilkan koefisien untuk variabel bebas adalah $\mathrm{X} 1$ $=0,279$ dan $\mathrm{X} 2=0,270$, dengan konstanta $-0,074$. Maka dari itu dapat dihasilkan persamaan regresi berganda dalam penelitian ini adalah sebagai berikut: $\mathbf{Y}=$ -

\section{$0,074+0,279 \times 1+0,270 \times 2+e$}

Berdasarkan tabel 4.2 menunjukan bahwa nilai Adjusted $R$ Square adalah sebesar 0,706 yang menandakan bahwa variabel independen hanya $70,6 \%$ mempengaruhi variabel dependen, sedangkan sisanya yaitu sebesar $29,4 \%$ pengaruh dari faktor lain diluar model regresi. Standar Error dalam penelitian ini sebesar 1,581. Hal tersebut menunjukkan bahwa nilai dari kesalahan pengganggu atau nilai-nilai dari variabel lain yang tidak dimasukan dalam model persamaan regresi adalah sebesar 1,581.

Persepsi Kebermanfaat berpengaruh terhadap minat karyawan dalam menggunakan fintech.

Dari hasill pengujian statisttik $t$ Persepsi Kebermanfaatan memiliki nilai signifikan thitung sebesar 0,001 . Dari hasil uji statistik t pada persepsi kebermanfaatan nilai signifikan thitung lebih kecil dari 0,05 dan koefisien regresi memiliki nilai positif sebesar 0,279 , sedangkan thitung 3,512 lebih besar dari $t_{\text {tabel }} 2,015$. Dari hasil tersebut menunjukkan bahwa persepsi kebermanfaatan berpengaruh positif dan signifikan terhadap minat menggunakan Fintech.

Hal ini dapat diartikan bahwa semakin banyak manfaat yang diperoleh dan dirasakan karyawan Lima Motor
Subang maka semakin meningkatkan minat mereka untuk menggunakan Fintech, begitu pula sebaliknya semakin sedikit manfaat yang mereka peroleh dan mereka rasakan saat menggunakan Fintech maka akan semakin menurunkan minat mereka untuk menggunakan Fintech. Manfaat penggunaan terhadap minat menggunakan Fintech menekankan pada anggapan tentang manfaat yang akan diterima dalam penggunaan teknologi informasi tersebut. Manfaat berkaitan dengan produktifitas dan efektifitas kegunaan Fintech terutama jenis layanan keuangan epayment untuk melakukan suatu kegiatan transaksi pembayaran. Dengan demikian jika seseorang merasa bahwa Fintech bermanfaat bagi dirinya maka orang tersebut akan semakin berminat untuk menggunakannya, dan apabila merasa bahwa fintech tidak memberikan manfaat bagi dirinya, maka orang tersebut tidak akan menggunakan fintech.

Dari hasil pengujian hipotesis diketahui variabel manfaat mempunyai pengaruh yang paling dominan dibandingkan variabel kemudahan terhadap minat Menggunakan Fintech. Hal ini dapat diartikan bahwa mayoritas karyawan akan lebih berminat menggunakan Fintech dikarenakan manfaat yang mereka rasakan dan mereka peroleh dibandingkan kemudahan menggunakan Fintech.

Hasil penelitian ini sesuai dengan penelitian Wildan (2019) Hasil penelitian menunjukkan bahwa Persepsi kemudahan penggunaan berpengaruh positif dan signifikan terhadap minat bertransaksi menggunakan Fintech. Hasil penelitian ini juga sesuai dengan penelitian Davis (1989) yang membuktikan bahwa manfaat mempunyai hubungan yang kuat dan konsisten dengan penerimaan teknologi informasi dibandingkan dengan variabel lain. Karyawan yang telah merasakan 
bahwa penggunaan Fintech pada jenis epayment mampu menambah tingkat produktifitas, meningkatkan efektifitas, sehingga dapat dikatakan bahwa secara keseluruhan Fintech merupakan sistem yang bermanfaat bagi karyawan akan mendorong karyawan untuk meningkatkan penggunaan Fintech. Implikasinya adalah Persepsi kemudahan berpengaruh terhadap minta karyawan dalam menggunakan fintech. Dari hasill pengujian statisttik t Persepsi Kemudahan memiliki nilai signifikan thitung sebesar 0,006 . Dari hasil uji statistik $t$ pada persepsi kemudahan nilai signifikan thitung lebih kecil dari 0,05 dan koefisien regresi memiliki nilai positif sebesar 0,270 sedangkan $t_{\text {hitung }}$ 2,894 lebih besar dari tabel 2,015. Dari hasil tersebut menunjjukan bahwa persepsi kemudahan berpengaruh positif dan signifikan terhadap minat menggunakan Fintech.

Hal ini dapat diartikan bahwa semakin besar kemudahan yang diperoleh karyawan Lima Motor Subang maka semakin meningkatkan minat mereka untuk menggunakan Fintech, begitu pula sebaliknya semakin sedikit kemudahan yang mereka peroleh saat menggunakan Fintech maka akan semakin menurunkan minat mereka untuk menggunakan Fintech.

Hal ini sesuai dengan pendapat Venkatesh dan Davis (2000) seperti yang dikutip Hanafi dkk (2012) dalam penelitiannya dimana persepsi kemudahan menimbulkan percaya diri dan rasa aman dalam aktivitasnya sehingga seseorang bersedia meningkatkan penggunaan. Semakin mudah persepsi mahasiswa dalam menggunakan website UB semakin besar tingkat percaya dirinya untuk menggunakannya. membagi dimensi persepsi kemudahan penggunaan menjadi berikut: Interaksi individu dengan sistem jelas dan mudah dimengerti, tidak dibutuhkan banyak usaha untuk berinteraksi dengan sistem tersebut, sistem mudah digunakan, dan mudah mengoperasikan sistem sesuai dengan apa yang ingin individu kerjakan .

Hasil penelitian ini sesuai dengan penelitian Herlambang, Dewayanti (2018) bahwa kemudahan dalam mengoperasikan aplikasi juga menjadi perhatian bagi penggunanya. Karena aplikasi yang bersifat user friendly dapat membuat pengguna merasa nyaman untuk mengoperasikannya.

Hasil penelitian Adiyanti (2015) juga memberikan bukti empiris bahwa kemudahan penggunaan teknologi produk baru akan mempengaruhi minat pengguna dalam bertransaksi menggunakan emoney. Semakin mudah dalam menggunakan teknologi baru maka minat seseorang dalam menggunakan produk baru akan semakin bertambah. Dikarenakan ketika produk baru mudah digunakan maka pengguna tidak perlu mempelajari lebih mendalam yang dapat membuang waktu dan tenaga mereka, sehingga kemudahan penggunaan akan berpengaruh secara signifikan dalam mempengaruhi minat seseorang.

\section{KESIMPULAN}

Hasil penelitian menunjukkan bahwa variabel persepsi kebermanfaatan dan persepsi kemudahan berpengaruh positif terhadap minat karyawan dalam menggunakan Fintech. Hal tersebut menunjukkan bahwa semakin bermanfaat dan semakin mudah maka minat karyawan dalam menggunakan Fintech akan meningkat.

Implikasinya dari hasil penelitian ini bahwa dikemudian hari seiring dengan peningkatan penggunaan layanan produk fintech dikalangan masyarakat, maka harus dibarengi pula dengan perkembangan teknologi dan informasi 
yang dapat memberikan kemudahan dan manfaat dalam penggunaan layanan produk fintech tersebut. Hal ini juga memungkinkan munculnya persaingan dikalangan pemilik aplikasi untuk terus berupaya memberikan layanan melalui fasilitas-fasilitas yang dapat ditawarkan melalui aplikasinya, sehingga masyarakat dapat dengan mudah menggunakan layanan produknya, dan menerima manfaat yang lebih dari apa yang meraka harapkan. Selain itu masyarakat juga harus lebih bijak dalam menggunakan fintech.

Adapun saran yang dapat disampaikan adalah diharapkan bagi pengembang Fintech dapat meningkatkan lagi aplikasi dari produk Fintech agar pengguna dapat menikmati produk Fintech tanpa kesulitan dan tanpa rasa takut dalam menggunakan Fintech. Bagi peneliti selanjutnya, penelitian ini dapat dijadikan referensi dalam pengembangan Fintech di lingkungan kerja dan dapat mengembangkan penelitian ini menggunakan faktor-faktor lain selain dalam penelitian ini yang mempengaruhi minat dalam menggunakan Fintech.

\section{REFERENCES}

Amalia Siti Nur Annisa (2018) FaktorFaktor Yang Mempengaruhi Minat Individu Terhadap Fintech Syariah (Paytren) Sebagai Salah Satu Alat Transaksi Pembayaran (Pendekatan Technology Acceptance Model (TAM) Dan Theory Of Planned Behavior (TPB).

Arief Wibowo. (2006). Kajian Tentang Perilaku Pengguna Sistem Informasi dengan Pendekatan Technology Acceptance Model (TAM). Diambil dari:http://peneliti.budiluhur.ac.id/w $\mathrm{p}$ content/uploads/2008/.../arif+wibo wo.pdf, pada tanggal 15 Agustus 2019

Ari, D. P. S. (2013). Pengaruh Technology Acceptance Model dan Pengembangannya dalam perilaku Menggunakan Core Banking System. Jurnal Keuangan dan Perbankan, Vol 17, No. 2, Mei 2013 Bambang Pratama, Mengenal Lebih Dekat Financial Technology, 2016.

Bank Indonesia, Surat edaran No.18/22/DKSP "Penyelenggaraan Layanan Keuangan Digital" 2016.

Bungin, Burhan. (2005). Metodologi Penelitian Kuantitatif Edisi Kedua. Jakarta : Kencana. HIm 72

Davis, F.D. 1989. Perceived usefulness, perceived Easy of Use, and User Acceptance of information Technology, MIS Quarterly

Davis, F. D., Bagozzi, R. P., \& Warshaw, P. R. (1989). User Acceptance of Computer Technology: A Comparison of Two Theoretical Models. Management Science, 35(8), 982-1003. https://doi.org/10.1287/mnsc.35.8. 982

Elshabyta Auditya Bintarto, (2018) Fintech dan cashless society: sebuah revolusi pendongrak ekonomi kerakyatan.

Hadi Syamsul, Novi. 2015 Faktor-Faktor Yang Mempengaruhi Penggunaan Layanan Mobile Banking. jurnal.fe.uad.ac.id/

Hartono, Jogiyanto. (2007). Sistem Informasi Keperilakuan. Yogyakarta: Andi.

Irmadhani, Mahendra Adhi, Nugroho. (2012) Pengaruh Persepsi Kebermanfaatan, Persepsi Kemudahan Penggunaan Dan Computer Self Efficacy, Terhadap Penggunaan Online Banking Pada Mahasiswa S1 Fakultas Ekonomi Universitas Negeri Yogyakarta 
Junadi, \& Sfenrianto. (2015). A Model of Factors Influencing Consumer's Intention to Use E- 60 payment System in Indonesia. Procedia Computer Science, 59(Iccsci), 214-220.

https://doi.org/10.1016/i.procs.201 $\underline{5.07 .557}$

Khoirul Basyar, Sanaji (2016) Pengaruh Persepsi Kemudahan Dan Persepsi Manfaat Terhadapniat Beli Ulang Secara Online Dengan Kepuasan Sebagai Variabel Intervening

Muchammad Fauzi, Metode Penelitian Kuantitatif: Sebuah Pengantar, Semarang: Walisongo Press, 2009, hlm.167

Rahayu, Rurie Wiedya (2018)Pengaruh Persepsi Manfaat, Persepsi Kemudahan, Persepsi Risiko, Dan Inovasi Teknologi Terhadap Aplikasi Go Pay Dari Pt.Gojek Indonesia (Studi Pada Masyarakat Di Kabupaten Sleman Dan Kota Yogyakarta)

Rithmaya, Chitra Laksmi. (2016). Pengaruh Kemudahan Penggunaan, Kemanfaatan, Sikap, Risiko dan Fitur Layanan Terhadap Minat Ulang Nasabah Bank BCA Dalam Menggunakan Internet Banking. Jurnal Riset Ekonomi dan Manajemen, Vol. 16, No. 1, 160177.

Ricki Yuliardi dan Zuli Nuraeni. (2017). “ Statistika Penelitian". Innosain:Yogyakarta.hlm. 93

Rithmaya, Chitra Laksmi (2016) Pengaruh Kemudahan Penggunaan, Kemanfaatan, Sikap, Risiko Dan
Fitur Layanan Terhadap Minat Ulang Nasabah Bank Bca Dalam Menggunakan Initernet Banking Sugiyono, Metode Penelitian Kuantitatif Kualitatitif dan R\&B, Bandung: Alfabeta. 2011. HIm.61.

Umi Narimawati dan Dadang Munandar. (2008). "Teknik Sampling: Teori dan Praktik dengan menggunakan SPSS 15". Gava Media:Yogyakarta. HIm. 29

Ventaketsh, \& Davis, F. D. (2000). A Theoretical Extension of the Technology Acceptance Model: Four Longitudinal Field Studies. Management Science. Vol. 46 No. 2: pp. 186- 504.

Widiyanto, I dan Prasilowati, S.L. (2015).

Perilaku Pembelian Melalui Internet, JMK, VOL, 17, No.2, September 2015, 109-112 DOI: 10.9744/jmk, 17.2.109-112 ISSN 1411-1438 print / ISSn 2338-8234.

Wildan, Muhammad (2019) Pengaruh Persepsi Kemudahan Penggunaan, Efektivitas Dan Risiko Terhadap Minat Bertransaksi Menggunakan Financial Technology (Fintech)

Yahyapor, Nina. (2008) Determining Factors Affecting Intention to Adopt Banking Recommender System, Case of Iran, Thesis, Lulea University of Technology Division of Industrial Marketing and ECommerce.

Yaumil Sarah, Salekha. (2017) Pengaruh Kemanfaatan Dan Kemudahan Terhadap Minat Nasabah Dalam Menggunakan E-Pay Bri (Studi Kasus Pada Bank Bri Cabang Slamet Riyadi 